\title{
Prevalence of HCV among the high risk groups in Khyber Pakhtunkhwa
}

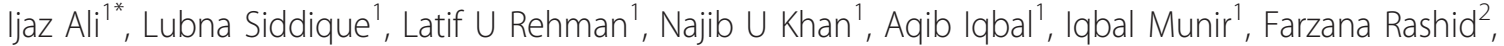 \\ Sana U Khan ${ }^{3 *}$, Safira Attache ${ }^{1}$, Zahoor A Swati ${ }^{1}$ and Mehwish S Aslam ${ }^{1}$
}

\begin{abstract}
Hepatitis $C$ is an infectious disease, caused by blood borne pathogen; the Hepatitis $C$ Virus. In this study we analyzed blood samples collected from various risk groups for the prevalence of anti-HCV and active HCV infection with the help of Immunochromtographic tests and nested PCR. The prevalence of active HCV infection among the high risk groups was 15.57\% (26/167). The prevalence of HCV in individual risk groups was 15\%, 28\%, 8\%, 14.28\% and $14.28 \%$ in the case of thalassemics, dialysis, major surgery group, dental surgery group and injection drug users respectively. Our analysis reveals the fact that health care facilities in the Khyber Pakhtunkhwa province of Pakistan are contributing a great deal towards the spread of HCV infection.
\end{abstract}

\section{Introduction}

Hepatitis $C$ is an infectious disease affecting the liver, caused by the hepatitis $\mathrm{C}$ virus (HCV). $\mathrm{HCV}$, a member of the Flaviviridae family, was discovered as a new viral agent causing non- $\mathrm{A}$, non- $\mathrm{B}$ hepatitis by $\mathrm{Choo}$ and coworkers in 1989 [1]. WHO estimated the global prevalence of Hepatitis $\mathrm{C}$ as 3\% [2]. In developing countries where resources and facilities may be significantly limited, the prevalence of $\mathrm{HCV}$ is higher as compared to the developed world [3].

$\mathrm{HCV}$ is transmitted through contaminated blood transfusion, surgery, surgical instruments, dental surgery and excessive dental consultations, sexual contacts, drug abuses, sharing of the house hold items such as razors, toothbrushes and shaving from the barber [4-6]. Some health care procedures, i.e., surgical and dental treatments, have recently been indicated as risk factors for acute $\mathrm{HCV}$ [7]. In Pakistan, blood transfusion is still a major source of HCV transmission. Possible reasons for this include lack of resources, weak infrastructure, ill-equipped resources, poorly trained staff, inadequate policy implementation, frequent power breakdown and ineffective screening of blood donors for anti-HCV antibody [8]. Regular blood transfusion in patients with hereditary hemolytic anemia,

\footnotetext{
* Correspondence: bachakhan35@yahoo.com; Laila_28@ymail.com ${ }^{1}$ Institute of Biotechnology and Genetic Engineering, Khyber Pakhtunkhwa Agricultural University, Peshawar, Pakistan

${ }^{3}$ Kohat University of Science and Technology, Kohat, Pakistan

Full list of author information is available at the end of the article
}

particularly Thalassemia, has improved their overall survival, but carries a definite risk of acquisition of blood-borne virus infections, especially viral hepatitis [9].

Major risk factors associated with the transmission of HCV were never investigated at molecular level in Khyber Pakhtunkhwa. In this study, we have analyzed patients belonging to various risk groups for the prevalence of anti HCV and active HCV infection. The risk groups included thalasemics, major surgery group, dental surgery group, dialysis group and IDUs (Injection drug users).

\section{Methods and materials \\ Sampling}

After having approved the study by the ethics committee of the Institute of Biotechnology and Genetic Engineering, Peshawar, a total of 167 blood samples were collected from patients belonging to various risk groups including thalassemics, major surgery group, dental surgery group, injection drug users and dialysis group. Each individual duly signed a proforma containing information about his/her previous exposure to a risk factor, age, sex etc. $5 \mathrm{~mL}$ of blood sample was collected in EDTA-tubes in each case and immediately transported to IBGE for serum isolation. Sera were stored at $-20 \mathrm{C}$ until used. All experiments were performed inn accordance with the ethical standards of the Declaration of Helsinki. 
Immunochromatographic test (ICT)

Screening for $\mathrm{HCV}$ positive samples was carried out with the help of Immunochromatographic tests. Strips used were from accurate and Acon (Acon, USA) according to the manufacturers instructions. Samples positive by ICT were further processed for next step evaluation.

\section{RNA Extraction and RT-PCR}

HCV RNA was extracted from $100 \mu$ s serum by using Anagen RNA extraction kit (Purescript, USA) according to the manufacturer's instructions. Qualitative detection of serum HCV RNA was performed by Reverse transcription PCR as mentioned previously [10].

\section{Gel electrophoresis}

PCR products were analyzed on $2 \%$ agarose gel prepared in $0.5 \%$ TBE buffer, stained with Ethedium bromide $(10 \mu \mathrm{g} / \mathrm{ml})$ as florescent dye. A 100-bp DNA ladder (Gibco BRL) was used as DNA size marker. Gels were photographed using Alpha quant (Alpha Innotech).

The data was analyzed with SPSS version 10.0 for windows or Microsoft Excel. Frequencies of hepatitis $C$ in different risk groups were calculated in percentages.

\section{Results}

A total of 167 blood samples were screened including thalassemic patients, dialysis patients, people having major surgeries, people having undergone dental surgeries (minor and major) and injection drug users.

Initial screening was done for anti-HCV using ICT strips from two different sources. Confirmation of active HCV infection was carried out with the help of RT-PCR. Out of 167 samples, 26 (15.57\%) were HCV positive both for anti-HCV and HCV RNA. Prevalence of active HCV infection in individual risk groups was $15 \%, 28 \%, 8 \%$, $14.28 \%$ and $14.28 \%$ in thalasemics, dialysis, major surgery group, dental surgery group and injection drug users respectively (Table 1).

Exposure to various HCV risk factors is preferentially gender specific in our country mainly due to our social set up. Exposure of females to some of the risk factors is limited. Among the observed population, 104 (62.27\%) were male and $63(37.72 \%)$ were female out of which

Table 1 Prevalence of $\mathrm{HCV}$ in individual risk groups

\begin{tabular}{cccc}
\hline S.No & $\begin{array}{c}\text { Major Risk groups } \\
(\mathbf{N})\end{array}$ & ICT positive & PCR positive \\
\hline 1 & Thalassemia (40) & $6(15 \%)$ & $6(15 \%)$ \\
\hline 2 & Dialysis (25) & $7(28 \%)$ & $7(28 \%)$ \\
\hline 3 & Major surgery (25) & $2(8 \%)$ & $2(8 \%)$ \\
\hline 4 & Dental surgery (35) & $5(14.28 \%)$ & $5(14.28 \%)$ \\
\hline 5 & IDUs (42) & $6(14.28 \%)$ & $6(14.28 \%)$ \\
\hline Total & 167 & $26(15.56 \%)$ & $26(15.56 \%)$ \\
\hline
\end{tabular}

18 (17.30\%) males and 8 (12.68\%) females were positive for anti-HCV as well as HCV RNA (Table 2). In terms of age distribution, the subjects were grouped into three categories Lowest prevalence (12.20\%) was recorded in the case of patients with age 15 years or below, while in the case of older age group (50 years and above), the highest HCV prevalence (22.22\%) was recorded (Figure 1).

Out of the total 167 samples from different risk groups included in the study, $3.59 \%$ were positive in the case of thalassemia, $4.19 \%$ in dialysis, $1.19 \%$ in major surgery, $2.99 \%$ in dental surgery and $3.59 \%$ in injection drug users. Highest prevalence was observed in dialysis patients (Table 3). Major risk factors for HCV transmission in KPK turned out to be dialysis followed by Thalasemia, Injection drug use and dental surgery.

\section{Discussion}

Thalassemia major patients are among the high risk groups for $\mathrm{HCV}$ infection. Earlier studies from various regions of Pakistan have reported high prevalence of HCV (20.5\%-60\%) among thalasemics [11-14] In this study The prevalence of anti-HCV or HCV RNA in individual group was $15 \%$ while among the high risk groups, it was $3.59 \%$ (Table 1,3 ) which is lower as compared to the previous estimates [15]. Majority of the studies undertaken in Pakistan have relied on anti-HCV detection in thalasemics using ICT devices and active infection was never investigated. The limitations of ICT devices for the detection of anti-HCV have been documented earlier [16]. Our own observation also reenforces the same [Unpublished data]. In KPK, where resources are extremely limited to screen anti-HCV, contaminated blood transfusion seems to be the most important factor contributing a great deal towards the spread of HCV in Thalasemic patients.

Major surgery also contributes towards HCV transmission. In Khyber Pakhtunkhwa province of Pakistan, the public sector hospitals are not adequately equipped for screening of blood and blood products and according to our own observation proper sterilization procedures are also not practiced due to various reasons including burden of patients undergoing surgeries or sometimes lack of awareness about the transmission of $\mathrm{HCV}$. Earlier studies reported the prevalence of $\mathrm{HCV}$ in major surgery groups as, $6.92 \%, 16.6 \%, 11.66 \%$ and

Table 2 Sex wise prevalence of active HCV infection

\begin{tabular}{lcccc}
\hline Sex & $\begin{array}{c}\text { Total } \\
\text { samples }\end{array}$ & $\begin{array}{c}\text { Positive } \\
\text { cases }\end{array}$ & $\begin{array}{c}\text { Negative } \\
\text { cases }\end{array}$ & $\begin{array}{c}\text { Prevalence } \\
\text { (\%) }\end{array}$ \\
\hline Male & 104 & 18 & 86 & $17.30 \%$ \\
\hline Female & 63 & 8 & 55 & $12.68 \%$ \\
\hline Total & 167 & 26 & 141 & $15.57 \%$ \\
\hline
\end{tabular}




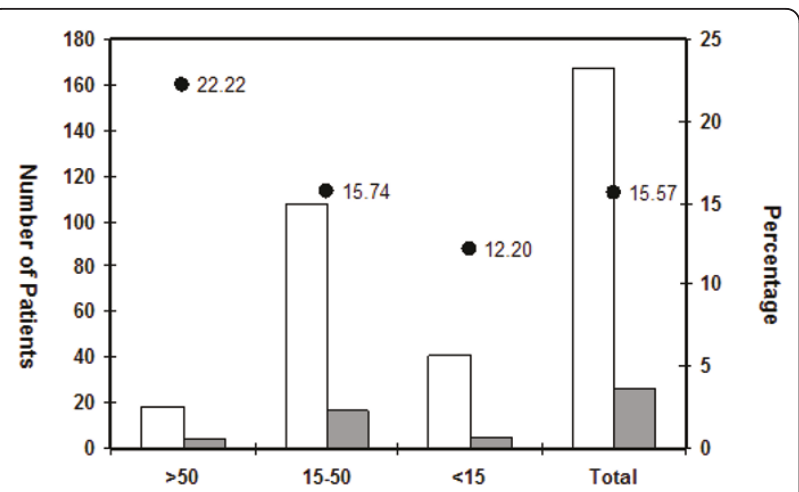

Figure 1 Age wise distribution of all the patients belonging to various risk groups. White bars represent total number of patients in each age group, grey bars represent HCV positive patients and filled circles show the percentage of HCV infected individuals.

$11.26 \%$ [17-20]. In this study, $2 / 25(8 \%)$ of the individuals with no history of $\mathrm{HCV}$ infection prior to major surgery turned out to be positive for anti-HCV and HCV RNA (Table 1). Though the prevalence of active $\mathrm{HCV}$ infection among the major surgery group is less than the previous reports, however it is still alarmingly high as compared to other parts of the world.

Dental surgery is one of the major risk factors for $\mathrm{HCV}$ transmission in Pakistan. Some studies have reported that dental procedures were the major source of exposure (39.7\%) followed by injections (16.6\%) and surgical procedures (16.6\%) [21]. Also the contaminated dentist equipments were the source of $\mathrm{HCV}$ infection in $17.94 \%$ people [22]. In this study the prevalence of anti-HCV and active $\mathrm{HCV}$ infection in the individual dental surgery group was $14.28 \%$. Detection of anti-HCV antibodies and HCV RNA in patients who have a recent history of dental surgery (major/minor) with no $\mathrm{HCV}$ infection prior to the surgery indicates that dental surgical and scaling instruments are not properly sterilized in our hospitals and clinics. Apart from the public sector hospitals, we observed that due to poor economic condition, many people consult dental quakes practicing in various parts of the province. None of the quakes were informed about the risk of $\mathrm{HCV}$ transmission as a result of contaminated equipments and they also were not aware about the sterilization procedures.

Hemodialysis is considered to be one of the major risk factors for $\mathrm{HCV}$ transmission. Some earlier studies reported that the prevalence of $\mathrm{HCV}$ in hemodialysis patients was 68\% in Pakistan, 23.7\% in Quetta and $24.7 \%$ in Lahore [23-25]). In India the prevalence of anti $\mathrm{HCV}$ is recorded as high as $83 \%$ in hemodialysis patients [26]. In this study the prevalence of anti-HCV antibodies and HCV RNA to be the highest as it was $28 \%$ in the individual risk group and $4.19 \%$ among the high risk groups (Table 3). The highest prevalence of $\mathrm{HCV}$ in dialysis group indicates the limitations of the screening procedures used in these units for the detection of anti-HCV.

It is evident from the previous studies conducted in Pakistan that injection drug use is a predominanat mode of $\mathrm{HCV}$ transmission [27,28]. $60 \%$ of the hepatitis C transmission in the United States is attributed to injection drug use [29] and 52\% in Tehran [30]. In this study, prevalence of anti-HCV and HCV RNA among the IDUs was $14.28 \%$ in the individual group of IDUs while it was $3.59 \%$ among the entire load of samples tested. None of the IDUs had a previous history of blood transfusion or surgeries but all of them did share needles in the past. Although, awareness about needle sharing has increased in recent times, yet the poorly educated IDUs of KPK did not seem to be aware of the risk of needle sharing.

It is also noted in this study that the prevalence of $\mathrm{HCV}$ was higher in males $(17.30 \%)$ as compared to females (12.68\%) which is in conformity with another local study [18]. Higher prevalence of $\mathrm{HCV}$ in males is probably due to exposure to numerous risk factors. According to our cultural environment, females are only negligibly exposed to some of the risk factors e.g. tattooing, injection drug use, barbers etc. Higher prevalence in males seems to be associated with our cultural attributes.

\section{Conclusion}

Lack of proper blood screening facilities in Khyber Pakhtunkhwa province and the lack of awareness about the possible transmission routes of $\mathrm{HCV}$ are contributing a great deal towards the spread of the infection among the population. Proper sterilization and screening procedures must be made mandatory on public sector health care units so as to avoid a far bigger threat of more $\mathrm{HCV}$ infections in the near future. The policy makers should formulate laws and ensure its implementation with respect to banning the unqualified dental quakes working in various parts of the province.

Table 3 Prevalence of HCV among the high risk groups

\begin{tabular}{cccccccc}
\hline Sex & Total samples & HCV positive & Thalassemia & Dialysis & Major surgery & Dental surgery & IDUs \\
\hline Male & 104 & 18 & & 5 & Nil & 2 & 6 \\
\hline Female & 63 & 8 & 1 & 2 & 2 & 3 & Nil \\
\hline Total & 167 & 26 & 06 & 07 & 02 & 05 \\
\hline & & $15.56 \%$ & $3.59 \%$ & $4.19 \%$ & $1.19 \%$ & $2.99 \%$ & $3.59 \%$ \\
\hline
\end{tabular}




\section{Author details}

'Institute of Biotechnology and Genetic Engineering, Khyber Pakhtunkhwa Agricultural University, Peshawar, Pakistan. ${ }^{2}$ Lahore College for Women University, Lahore, Pakistan. ${ }^{3}$ Kohat University of Science and Technology, Kohat, Pakistan.

\section{Authors' contributions}

IA designed the study and advised about the protocols. LS, LR, Al and SA carried out sampling, experimental procedures and manuscript preparation. MSA helped LS with lab work plus manuscript preparation. MSA, SK, IM, FR and ZAS critically reviewed and approved the manuscript. All authors read and approved the final manuscript.

\section{Competing interests}

The authors declare that they have no competing interests.

Received: 18 March 2011 Accepted: 11 June 2011

Published: 11 June 2011

\section{References}

1. QL Choo, G Kuo, AJ Weiner, LR Overby, DW Bradley, M Houghton, Isolation of a CDNA clone derived from a blood-borne non-A, non-B viral hepatitis genome. Science. 244, 359-362 (1989). doi:10.1126/science.2523562

2. WHO, Diseases; HepatitisC. http://www.who.int/csr/disease/hepatitis/ whocdscsrlyo2003/en/index3.html. Accessed in 2011

3. CP Wild, AJ Hall, Primary prevention of hepatocellular carcinoma in developing countries. Mutat Res. 462, 381-393 (2000). doi:10.1016/S13835742(00)00027-2

4. RP Perrillo, Factors influencing response to interferon in chronic hepatitis B: implications for Asian and western populations. Herpetology. 12, 1433-5 (1990)

5. S Sato, S Fujiyama, M Tanaka, Confection of hepatitis $\mathrm{C}$ virus in patients with chronic hepatitis B infection. J Hepatol. 21, 159-66 (1994). doi:10.1016/ S0168-8278(05)80389-7

6. SA Van, A Hardon, Injection practices in the developing world. World Health Organization. 15-43 (1997)

7. A Mele, ME Tosti, A Marzolini, A Moiraghi, P Ragni, G Gallo, E Balocchini, E Santonastasi, T Stroffolini, Prevention of hepatitis $C$ in Italy: lessons from surveillance of type-specific acute viral hepatitis. J Viral Hepatitis. 7, 30-35 (2000). doi:10.1046/j.1365-2893.2000.00179.x

8. S Akhtar, T Moatter, Hepatitis C virus infection in polytransfused thalassemic children in Pakistan. Indian Pediatr. 41, 1072-1073 (2004)

9. SM Alavian, P Adibi, MR Zali, Hepatitis C virus in Iran: Epidemiology of an emerging infection. Arch Iranian Med. 8, 84-90 (2005)

10. A Ali, H Ahmad, A Ali, S Khan, G Zaidi, M Idrees, Prevalence of active hepatitis $C$ virus infection in district mansehra Pakistan. Virol J Biomed Central. 7, 334 (2010)

11. FA Bhatti, M Amin, M Saleem, Prevalence of antibody to hepatitis $C$ virus in Pakistani thalassaemics by particle agglutination test utilizing C 200 and C 22-3 viral antigen coated particles. J Pak Med Assoc. 45, 269-71 (1995)

12. T Shamsi, A Ahmad, Z Taj, Prevalence of hepatitis B, C and HIV virus infection among beta thalassaemia major patients. Pak J Med Res. 48, 87 (1998)

13. H Hamid, R lqbal, MH Khan, B Iftikhar, S Aziz, FK Burki, J Sethi, M Hassan, YB Nisar, J Krishan, Prevalence of hepatitis $C$ in beta thalassaemic major. Gomal J of Med Sciences. 6, 2 (2008)

14. S Akhtar, T Moatter, SI Azam, MH Rahbar, S Adil, Prevalence and risk factors for interfamilial transmission of hepatitis $C$ virus in Karachi, Pakistan. Baillieres Clin Haematol. 11, 147-49 (1998). doi:10.1016/50950-3536(98) 80073-5

15. WHO, Hepatitis C assays: Operational characteristics (Phase I and Phase II) Report 1 \& 2. (2001) WHO/BCT/BTS/01.5

16. M Rahman, SA Khan, Y Lodhi, Unconfirmed reactive screening tests and their impact on donor management. Pak J Med Sci. 24(4):517-9 (2008)

17. UK Najib, S Lubna, A ljaz, I Aqib, M lqbal, R Farzana, A Sajid, R Fazal, AS Zahoor, Prevalence of hepatitis B in the blood donors of NW.F.P and FATA regions and the current scenario of HBV infection in Pakistan. African Journal of Biotechnology. 6162-6166 (2010)

18. N Muhammad, Frequency of hepatitis C in Buner, NWFP. J Coll Physicians Surg Pak. 15, 11-4 (2005)
19. AT Altaf, AG Ansari, MS Awan, AA Ghumro, Prevalence of hepatitis 'B' and ' $C$ ' in surgical patients. Pak j Surgery. 22, 3 (2006)

20. IA Choudhary, SA Khan, Samiullah, Z Hayat, RU Rehman, M Zarif, Comparative Analysis Of risk factors and complications of hepatitis B and C infections at Khyber teaching hospital Peshawar. Hepatitis monthly. 2, 83-86 (2007)

22. AJ Mohammed, AA Qudah, KF Shishi, AA Sarayreh, LA Quraan, Hepatitis C virus (HCV) infection in hemodialysis patients in the south of Jordan. Renal data from the arab world. 20, 488-492 (2009)

23. A Gul, F labal, Prevalence of hepatitis $C$ in patients on maintenance haemodialysis. J Coll Physicians Surg Pak. 13, 15-18 (2003)

24. AZ Karim, K Shah, H Rehman, A Daud, J Ahmed, Hepatitis C virus infection in patients on long term hemodialysis. Gomal Journal of Medical Sciences. 6, 1 (2008)

25. F Shafiq, S Akram, N Hashmat, Prevalence of hepatitis $C$ in patients with end-stage renal disease before and during hemodialysis. Pak J Gastroenterol. 16, 17-20 (2002)

26. FH Pujol, JG Ponce, MG Lema, F Capriles, M Devesa, F Sirit, High incidence of hepatitis $C$ virus infection in hemodialysis patients in units with high prevalence. J din Microbiol. 34, 1633-6 (1996)

27. I Kuo, S ul-Hasan, N Galai, DL Thomas, T Zafar, MA Ahmed, SA Strathdee, High HCV seroprevalence and HIV drug use risk behaviors among injection drug users in Pakistan. Harm Reduct J. 3, 26 (2006). doi:10.1186/1477-75173-26

28. M Achakzai, M Kassi, PM Kasi, Seroprevalences and coinfections of HIV, hepatitis C virus and hepatitis B virus in injecting drug users in Quetta, Pakistan. Trop Doct. 37, 43-45 (2007). doi:10.1258/004947507779951989

29. MJ Alter, HS Margolis, K Krawczynski, FN Judson, A Mares, WJ Alexander, PY Hu, JK Miller, MA Gerber, RE Sampliner, LM Emory, D Meeks, MJ Beach, The natural history of community-acquired hepatitis $C$ in the united states: The sentinel counties chronic non-a, non-b hepatitis study team. The New England journal of medicine. 327, 1899-1905 (1992). doi:10.1056/ NEJM199212313272702

30. S Zamani, S Ichikawa, B Nassirimanesh, M Vazirian, K Ichikawa, MM Gouya, P Afshar, MO Kihara, SM Ravari, M Kihara, Prevalence and correlates of hepatitis C virus infection among injecting drug users in Tehran. Int I Drug Policy. 18, 359-363 (2007). doi:10.1016/j.drugpo.2007.02.007

doi:10.1186/1743-422X-8-296

Cite this article as: Ali et al.: Prevalence of HCV among the high risk groups in Khyber Pakhtunkhwa. Virology Journal 2011 8:296.

\section{Submit your next manuscript to BioMed Central and take full advantage of:}

- Convenient online submission

- Thorough peer review

- No space constraints or color figure charges

- Immediate publication on acceptance

- Inclusion in PubMed, CAS, Scopus and Google Scholar

- Research which is freely available for redistribution

Submit your manuscript at www.biomedcentral.com/submit
Ciomed Central 